JURNAL SOSIAL-EKONOMI PERTANIAN DAN AGRIBISNIS

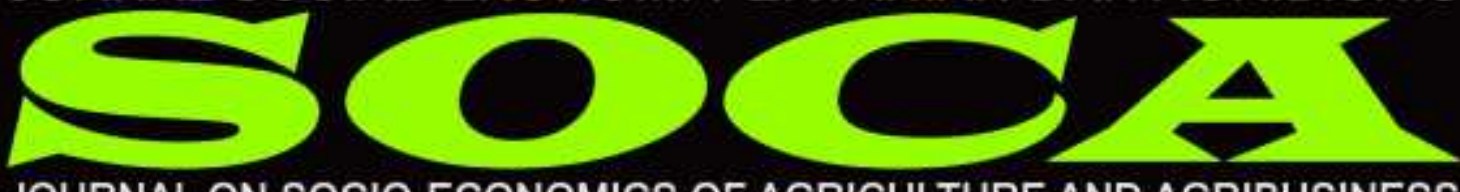

JOURNAL ON SOCIO-ECONOMICS OF AGRICULTURE AND AGRIBUSINESS

\title{
PERUBAHAN SOSIAL MASYARAKAT AKIBAT PENURUNAN KUALITAS PADI \\ DI DESA WONOJATI KECAMATAN JENGGAWAH KABUPATEN JEMBER
}

\begin{abstract}
Sofyan Ade Mustafa Harun, Mochammad Ivan Pradhipta dan Umar Achmad Universitas Jember, Jember, Jawa Timur

Email: sofyan04knb@gmail.com, ivanpradhipta@gmail.com dan umar.achmad7@gmail.com HP: 085964166512,089675713223 dan 087777143803
\end{abstract}

\begin{abstract}
ABSTRAK
Masyarakat di Desa Wonojati Kecamatan Jenggawah termasuk masyarakat yang secara cepat mengalami perubahan sosial. Kondisi ini diketahui dari banyaknya inovasi baru terkait pertanian yang mampu diterapkan masyarakat setempat. Penelitian ini bertujuan untuk membahas mengenai penyebab penurunan kualitas padi, dampak yang disebabkan karena adanya penurunan kalitas padi, dan upaya untuk mengatasi penurunan kualitas padi. Penelitian ini dilakukan menggunakan metode Focus Group Discussion, dengan informan kunci yaitu ketua kelompok tani, dan menggunakan snowball sampling untuk mendapatkan responden lain yang sesuai dengan tujuan penelitian. Hasil penelitian menunjukkan bahwa penurunan kualitas disebabkan oleh serangan hama dan penyakit, pemupukan berlebihan, penyempitan saluran air dan pendidikan masyarakat Desa Wonojati yang tergolong rendah. Dampak yang terjadi akibat penurunan kualitas, dapat dilihat dari aspek ekonomi dimana pendapatan petani semakin berkurang, dan social dimana terdapat hubungan yang kurang baik antar masyarakat. Upaya yang dilakukan untuk mengatasi penurunan kualitas padi yaitu melalui penyuluhan mengenai benih berkualitas dan pemupukan berimbang.
\end{abstract}

Kata Kunci: Perubahan sosial, Dampak, OPT, FGD

\section{SOCIAL CHANGE OF THE SOCIETY AS THE RESULT OF THE DECREASING OF RICE QUALITY IN WONOJATI VILLAGE SUB-DISTRICT JENGGAWAH JEMBER DISTRICT}

\begin{abstract}
The people in Wonojati Village jenggawah Sub-District are included in fast social change. This codition known from so many new inovation about agriculture that can be adapted by the society. This research disscuss about cause of the decresing of rice Quanlity, the effect from the deceasing of rice quality, and the effort to overcome the problem about the decresing of rice quality. This research use Focus Group Discussion
\end{abstract}


method, with the key informan is the chief of the farmers group, and then use snowball sampling to get another respondent that suitable for the purpose of the research. The result show that the decreasing of rice quality is because of pests and diseases, excessive fertilization, narrowing of waterways and the low education from the people of Wonojati village. The effect of the decresing of rice quality can be seen through economics effect that the farmers income is decreasing and social effect that there are a bad relatins beetwen farmers. The effort that can be done to overcome this decresing of rice quality is to have an agricultural counseling about the using of verification seeds and balanced fertilizations.

Keywords: Social Change, Effect, OPT, FGD

\section{PENDAHULUAN}

Pertanian merupakan suatu aktivitas yang memanfaatkan sumber daya alam yang dikelola oleh manusia untuk menghasilkan bahan pangan. Pertanian Indonesia memiliki pengaruh terbesar untuk kemajuan perekenomian nasional. Pertanian sendiri menjadi tumpuan utama masyarakat untuk memenuhi kebutuhan. Pertanian dijadikan sebagai salah satu sektor yang mampu menyediakan lapangan pekerjaan dan memberikan devisa bagi negara melalui jalur ekspor. Fungsi pertanian yang seperti ini terus menjadi gambaran pertanian Indonesia sejak dulu. Melihat dari sistem pertanian desa saat ini, hasil dari pertanian bukan hanya untuk ekspor lagi, melainkan juga sebagai pemenuhan kebutuhan petani.

Martono (2012) mengemukakan bahwa perubahan sosial adalah perubahan yang terjadi pada masyarakat mengenai nilai-nilai sosial, norma, dan berbagai pola dalam kehidupan manusia. Hakikatnya, setiap masyarakat diseluruh dunia akan mengalami perubahan-perubahan yang diketahui jika membandingkan suatu masyarakat di masa tertentu dengan masyarakat di masa lampau. Masyarakat pada dasarnya dapat dikatakan bahwa terus menerus mengalami perubahan. Perubahan antara masyarakat yang satu dengan masyarakat yang lain tidak selalu sama karena terdapat suatu masyarakat dengan perubahan yang lebih cepat dibandingkan dengan masyarakat lainnya. Masalah sosial yang muncul di masyarakat hampir semuanya merupakan konsekuensi perubahan sosial. Perubahan tersebut dapat berupa perubahan yang kecil sampai pada taraf perubahan yang sangat besar.

Perubahan sosial melibatkan masyarakat yang bersangkutan dan orang luar yang mengamati. Perubahan dapat berupa perubahanperubahan yang tidak menarik, perubahan-perubahan yang pengaruhnya terbatas maupun yang luas, dan perubahan-perubahan yang lambat sekali maupun berjalan cepat. Perubahan-perubahan di dalam masyarakat dapat mengenai nilai sosial, pola-pola perilaku, organisasi susunan, lembaga-lembaga kemasyarakatan dalam masyarakat, kekuasaan, wewenang, dan interaksi sosial. Perubahan ini dikarenakan interaksi sosial antar dapat mempengaruhi pola pikir maupun tindakan manusia. Perubahan sosial dalam kehidupan manusia tidak bisa dilihat dari satu sisi, melainkan banyak faktor yang menyebabkan manusia melakukan perubahan 
walaupun perubahan tersebut tidak diinginkan (Andriani, 2012).

Masyarakat di Desa Wonojati termasuk masyarakat yang cepat mengalami perubahan sosial. Kondisi ini diketahui dari banyaknya inovasi baru terkait pertanian yang mampu diterapkan masyarakat setempat. Perubahan sosial yang terjadi pada petani di Desa Wonojati yaitu penggunaan teknologi seperti penggunaan bahan kimia sebagai pengendalian hama dan penyakit tanaman. Petani Desa Wonojati mengalami permasalahan dalam kegiatan pertaniannya yaitu serangan hama pada tanaman padi. Budidaya tanaman padi di Desa Wonojati merupakan kegiatan utama yang dilakukan masyarakat setempat sebagai kegiatan ekonominya. Perubahan sosial yang terjadi di Masyarakat desa Wonojati terjadi karena adanya permasalahan akibat penurunan kualitas padi. Kendala yang dihadapi dalam kegiatan ini adalah tingginya intensitas serangan hama padi yang dapat menurunkan produktifitas padi baik secara kuantitas maupun kualitas. Penelitian ini bertujuan untuk mengetahui penyebab menurunnya kualitas komoditas padi, dampak adanya penurunan serta upaya untuk mengatasi penurunan kualitas padi tersebut. Penelitian ini penting dilaksanakan agar dapat menjadi salah satu solusi terkait masalah penurunan kualitas padi.

\section{METODE PENELITIAN}

Metode penelitian yang digunakan yaitu deskriptif kualitatif yang bertujuan untuk mendapatkan informasi terkait fenomena yang terjadi di daerah penelitian. Daerah penelitian yaitu Desa Wonojati Kecamatan Jenggawah Kabupaten jember. Pemilihan lokasi ini menggunakan purposive method dengan pertimbangan bahwa di Desa Wonojati terdapat fenomena penuruna kualitas padi.

Metode pengumpulan data yang digunakan adalah melalui wawancara, observasi lapang, dan Focus Group Discussion (FGD) untuk memperoleh data primer, sedangkan untuk mendapatkan data sekunder menggunakan dokumentasi. Penetuan informan melalui teknik snowball sampling dimana proses penentuan informan berdasarkan informan sebelumnya tanpa menentukan jumlahnya secara pasti dengan menggali informasi terkait topik penelitian yang diperlukan. Informan utama dalam penelitian ini adalah Ketua kelompok tani yang selanjutnya akan mengarahkan kepada informaninforman lainnya.

Penentuan Key Informan dilakukan melalui method purposive sampling. Menurut Yusuf (2017), purposive sampling merupakan penentuan sumber informasi dilandasi tujuan atau pertimbangan terlebih dahulu. Pemilihan ditentukan berdasarkan tujuan penelitian, dan kebutuha utama dari peneliti. Metode ini memudahkan peneliti untuk mengkaji bahasan penelitian secara mendalam karena seringkali informan yang dituju adalah yang berkompeten dalam bidangnya, seperti ketua kelompok tani. Informan dipilih berdasarkan kriteria yang dibutuhkan peneliti sebagai data untuk penelitian. Menurut Sugiyono dalam Sugiarto (2015), kriteria penentuan informan adalah sebagai berikut:

1. Mereka yang menguasai atau memahami sesuatu melalui proses enkulturasi sehingga sesuatu itu bukan sekedar diketahui namun juga dihayatinya.

2. Mereka yang tergolong masih sedang berkecimpung atau 
terlibat pada kehiatan yang tengah diteliti.

3. Merek yang mempunyai waktu yang memadai untuk dimintai informasi

4. Mereka yang tidak cenderung menyampaikan informasi hasil kemasannya sediri.

5. Mereka yang pada mulanya tergolong "cukup asing" dengan peneliti sehingga lebih menggairahkan untuk dijadikan semacam guru atau narasumber.

Melalui kriteria tersebut peneliti dapat menentukan key informan yang sesuai dengan subjek penelitian.
Berdasarkan kriteria tersebut peneliti memilih seorang ketua kelompok tani karena memenuhi kriteria yang dibutuhkan untuk penelitian. Pemilihan ketua kelompok tani sebagai key informan diharapkan dapat membantu peneliti dalam upaya mengetahui fenomena dengan lebih baik dan juga sebagai media untuk pemenuhan informan yang lain melalui metode snowball sampling yang diarahkan langsung kepada petani petani lain yang tergabung sebagai anggota kelompok tani. Alur penentuan dapat dilihat dalam bagan dibawah.

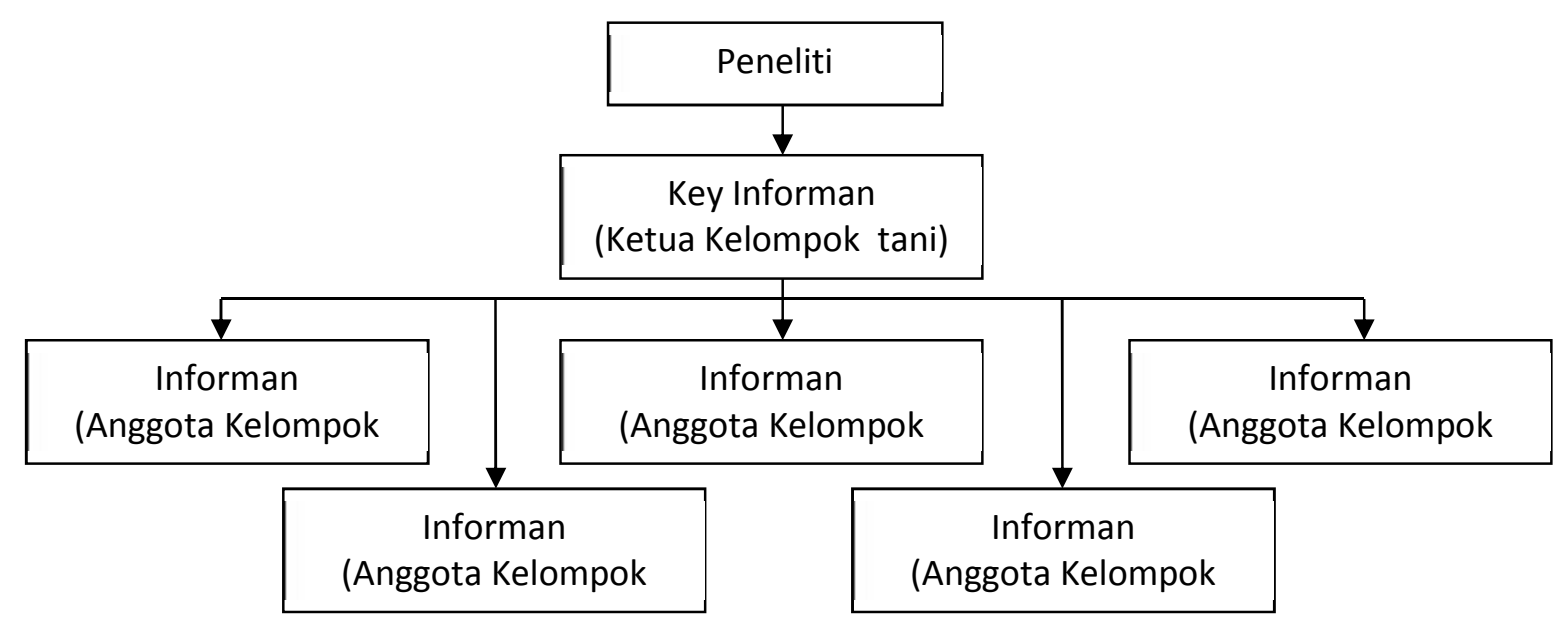

Gambar 1. Alur Penentuan Informan

\begin{abstract}
Informan yang digunakan berjumlah 15 orang dimana didalamnya terdapat 1 Ketua Kelompok tani dan 14 orang anggota kelompok tani. Anggota kelompok tani yang tergabung dalam diskusi merupakan anggota kelompok tani yang aktif dan merupakan saran dari ketua kelompok tani langsung.
\end{abstract}

Analisis data yang digunakan yaitu fishbone yang merupakan suatu metode untuk menganalisis permasalahan dengan menentukan masalah utama, masalah primer, masalah sekunder, dan masalah tersier serta solusi yang berasal dari kegiatan Focus Group Discussion (FGD) di Desa Wonojati Kecamatan Jenggawah Kabupaten Jember. 


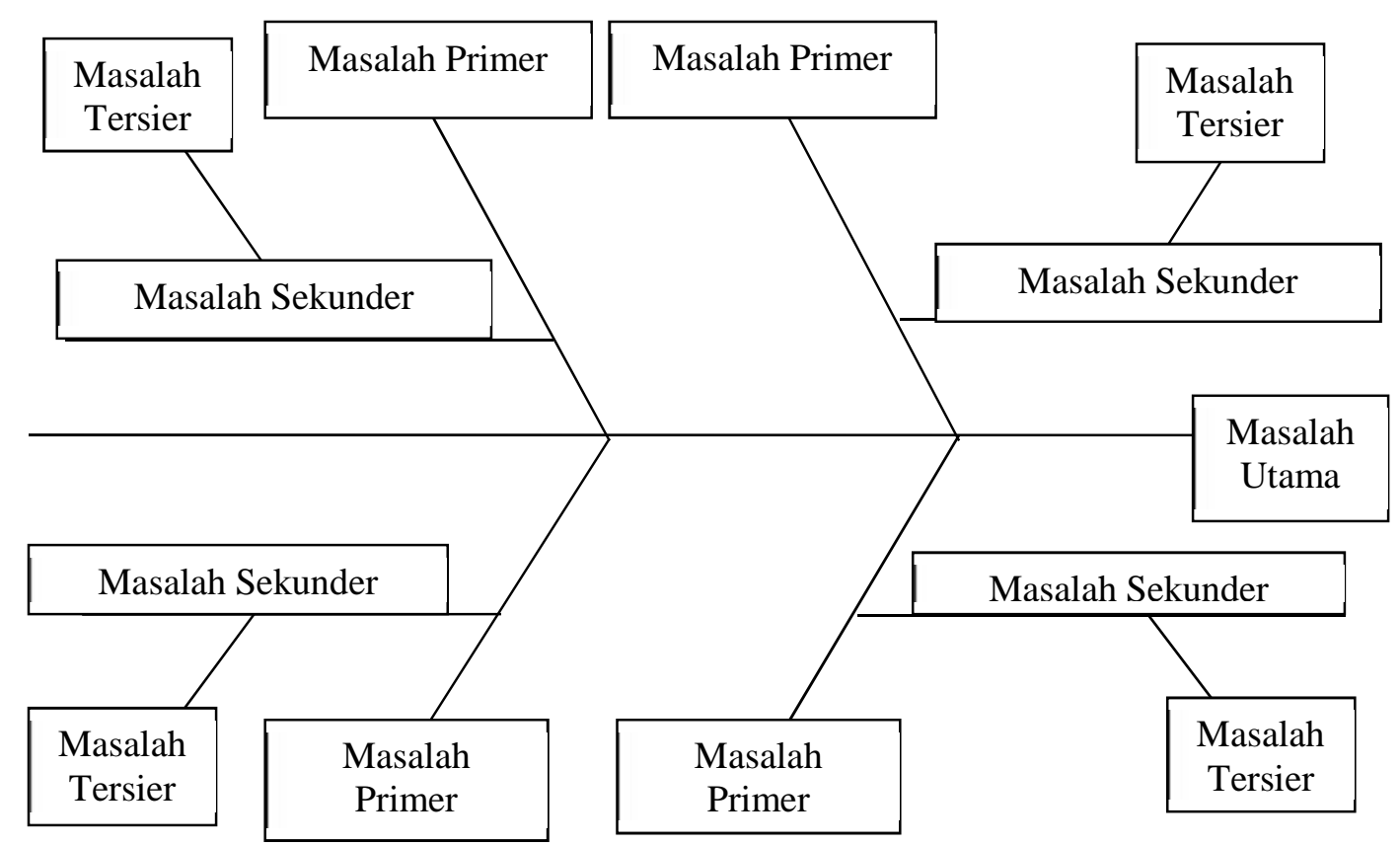

Gambar 2. Diagram Fishbone

\section{HASIL DAN PEMBAHASAN}

Desa Wonojati adalah salah satu desa yang terletak di Kecamatan Jenggawah yang merupakan bagian dari Kabupaten Jember. Desa Wonojati terletak pada $113^{\circ} \mathrm{LU}$ dan $8^{\circ} \mathrm{LS}$. Desa Wonojati berada pada ketinggian 0-3330 mdpl dengan suhu rata-rata $23^{\circ}-32^{\circ} \mathrm{C}$. Desa Wonojati memiliki total wilayah yang cukup luas. Desa Wonojati memiliki luas wilayah sebesar $5,75 \mathrm{~km}^{2}$. Luasan wilayah tersebut digunakan untuk berbagai macam kebutuhan masyarakat setempat. Wilayah seluas $2,59 \mathrm{~km}^{2}$ digunakan untuk sawah, $1,19 \mathrm{~km}^{2}$ untuk tegalan, $1,31 \mathrm{~km}^{2}$ untuk bangunan, dan $0,66 \mathrm{~km}^{2}$ untuk lainnya. Desa Wonojati didalamnya terdapat 8 rukun warga, dan 55 rukun tetangga. Desa Wonojati berbatasan langsung dengan lima desa yang berbeda. Bagian timur berbatasan dengan Desa Cangkring, bagian barat berbatasan dengan Desa Jenggawah, bagian selatan berbatasan dengan Desa Kertonegoro dan Desa Sruni, serta bagian utara berbatasan dengan
Desa Jenggawah. Berikut merupakan peta wilayah dari Desa Wonojati.

Desa Wonojati terdiri dari 4 dusun, yaitu Dusun Wetan Gunung, Dusun Pondok Lalang, Dusun Krajan, dan Dusun Bringin Lawang. Desa Wonojati memiliki posisi yang yang strategis dalam bidang pertanian dan sumber daya alam lainnya. Desa Wonojati memiliki jarak yang cukup jauh dari pusat kota jember yaitu sekitar $19 \mathrm{~km}$. Jarak tersebut tentunya akan mempengaruhi dalam kegiatan pertanian di Desa Wonoajati, misalnya dalam kegiatan pemasaran ke pusat Kota Jember akan memerlukan biaya lebih karena jaraknya yang jauh. Desa Wonojati memiliki sarana yang cukup memadai yang dapat membantu memenuhi kebutuhan masyarakat setempat.

Desa Wonojati merupakan daerah yang memiliki potensi dalam subsektor tanaman pangan, peternakan, dan perikanan. Subsektor yang paling tinggi yaitu subsektor pangan karena mayoritas masyarakat Wonojati memiliki lahan persawahan dan digunakan sebagai lahan budidaya tanaman padi dan jagung. 
Kedelai juga dikembangkan sebagai komoditas tambahan, namun tidak banyak masyarakat desa Wonojati yang melakukan budidaya tanaman kedelai dengan alasan karena harga kedelai yang konstan dan tidak ada kenaikan harga.

Kondisi pertanian di Desa Wonojati dapat dikatakan baik karena kondisinya tanah yang subur. Lahan pertanian di Desa Wonojati dimanfaatkan oleh petani untuk penanaman komoditas jagung, padi, dan kedelai dan tembakau. Komoditas utama di Desa Wonojati adalah padi. Berikut merupakan tabel komoditas pertanian.

Tabel 1. Hasil Produksi Pertanian di Desa Wonojati Tahun 2017

\begin{tabular}{rlcc}
\hline No & Komoditas & Luas lahan (Ha) & Hasil (Ton) \\
\hline 1. & Padi & 110 & 660 \\
2. & Jagung & 70 & 840 \\
3. & Kedelai & 50 & 150 \\
4. & Tembakau & 29 & 58 \\
\hline \multicolumn{4}{r}{ Jumlah }
\end{tabular}

Sumber: Data Olahan Profil Desa Wonojati

Produksi padi di Desa Wonojati sebesar 660 ton sedangkan untuk produksi jagung sebesar 840 ton dan kedelai 150 ton serta tembakau 58 ton. Pola musim tanam di Desa Wonojati adalah Padi-Jagung-Kedelai serta Padi-Padi-Kedelai-Tembakau. Tembakau jarang ditanam karena selain perawatnnya lebih susah para petani lebih banyak menanam padi karena biaya perawatan lebih murah dan konsumen lebih banyak mencari beras dari pada tembakau. Luas lahan yang dimanfaatkan untuk pertanian seluas 259 Ha.

Penyebab menurunnya kualitas padi yaitu akibat serangan dari hama wereng sehingga mengakibatkan gagal panen. Penurunan kualitas jagung akibat serangan bule, penyakit ini menyerang akar sehingga menyebabkan tanaman jagung mati. Serangan epidemi pada tanaman kedelai dibantu oleh hembusan angin sedangkan pada tanaman tembakau jenis hama yang sering menyerang adalah ulat daun yang akan memakan daun tembakau sampai habis.

\section{Penyebab Menurunnya Kualitas Komoditas Padi di Desa Wonojati Kecamatan Jenggawah Kabupaten Jember}

Tanaman padi sangat rentan terhadap serangan OPT akibat perubahan iklim yang tidak menentu. Petani perlu waspada dengan perkembangan OPT, utamanya yang bersumber dari musim tanam sebelumnya, perkembangan OPT memiliki intensitas yang cukup tinggi karena OPT yang sudah berkembang pada petanaman sebelumnya telah berkembangbiak dan tahan terhadap lingkungan sekitar, apabila para petani tidak mengganti pestisida yang digunakan untuk membasmi hama padi, maka perkembangan hama padi tersebut akan meningkat dan memiliki daya tahan tinggi terhadap pestisida yang diberikan sehingga besar kemungkinan tanaman padi mengalami penurunan kualitas dan produksinya. Faktor lingkungan biotik dan abiotik juga mempengaruhi kualitas tanaman padi.

Faktor biotik yang dapat mempengaruhi kualitas tanaman padi 
yaitu serangga yang dapat merugikan seperti hama. Penyakit juga merupakan faktor biotik yang dapat mempengaruhi kualitas tanaman padi, apabila tanaman terkena penyakit maka tanaman padi tersebut akan turun kualitasnya bahkan bisa mati. Gulma tanaman juga dapat menurunkan kualitas tanaman padi dan dapat menurunkan produksi padi. Faktor abiotik yang dapat mempengaruhi kualitas tanaman padi yaitu iklim, tanah, ketersediaan air, dan nutrisi. Penggunaan pestisida kimia dan pupuk tidak berimbang dapat mengakibatkan kondisi lahan pertanian menjadi tidak sehat sehingga lahan mendukung dalam proses perkembangbiakan OPT.

Pemberian pupuk berimbang dilakukan untuk mengefektifkan dan mengefisiensikan penggunaan pupuk anorganik dengan memperhatikan kebutuhan hara tanaman, atau memperhatikan spesifik wilayah. Pemberian pupuk anorganik secara berlebih dapat mengakibatkan tanah pertanaman menjadi tidak sehat dan dapat mengakibatkan tanah menjadi tidak sehat sehingga dapat mempengaruhi kualitas dan jumlah produksi yang dihasilkan. Penggunaan pupuk yang tidak berimbang dapat mendukung perkembangan OPT seperti hama yang dapat menyerang tanaman padi.

Hama wereng merupakan salah satu contoh OPT yang dapat mengganggu tanaman padi. Serangan hama wereng dapat mengakibatkan kerugian yang sangat besar apabila serangannya mencapai $90 \%$ populasi tanaman padi sehingga dapat menurunkan kualitas dan menurunkan produksi tanaman padi yang dihasilkan bahkan dapat mengakibatkan gagal panen. Hama wereng, utamanya wereng batang cokelat merupakan hama yang dapat berkembang secara cepat dan mudah merusak padi yang bersifat tahan. Gejala awal serangan hama wereng yaitu daun dan batang tanaman masih tetap hijau namun dikelili nimpa dan wereng dewasa, kemudian tahap selanjutnya serangan hama wereng coklat yaitu tanaman mengering akan tetapi masih berbentuk pada bagianbagian tertentu dan semakin lama akan menyatu sehingga daun dan batang yang terserang akan mengalami kekeringan dan berubah menjadi warna cokelat.

Musim kemarau dengan curah hujan yang tinggi juga merupakan salah satu faktor penyebab menurunnya kualitas tanaman padi. Hujan yang terus-menerus dapat mengakibatkan debit air yang ada pada lahan persawahan menjadi naik. Pertambahan volume air tersebut, apabila tiba-tiba terjadi selang hujan yang cukup lama maka air hujan tersebut akan menggenang dan dapat mengakibatkan tumbuh dan berkembangnya hama keong yang dapat merusak tanaman padi. Penyempitan saluran air yang disebabkan oleh penumpukan sampah juga dapat menyebabkan terjadinya genangan air yang dapat mengakibatnya perkembangan hama keong. Kondisi musim kemarau yang tiba setelah terjadi hujan tersebut dapat menyebabkan kekeringan pada lahan pertanaman padi ketika musim hujan tidak terjadi selama selang waktu yang cukup lama. Kekeringan tersebut merupakan hambatan yang dapat menyebabkan menurunnya kualitas padi yang diusahatanikan oleh petani.

Petani padi yang ada di Desa Wonojati belum bisa menerima saran dari penyuluh pertanian maupun dari pemerintah tentang penggunaan pupuk berimbang maupun penggunaan sistem tanam. Masyarakat di Desa Wonojati masih percaya dengan kebiasaan yang sudah 
turun-temurun dilakukan oleh keluarga petani tersebut. Penggunaan pupuk yang tidak berimbang dilakukan oleh petani di Desa Wonojati karena adanya anggapan bahwa semakin banyak menggunakan pupuk berbahan kimia, maka hasil produksi tanaman padi akan semakin meningkat. Kenyataan di lapang, tanaman padi yang dihasilkan oleh petani yang tidak menerapkan pupuk berimbang, jumlah produksinya lebih sedikit dibandingkan dengan petani yang menerapkan pupuk berimbang. Perbedaan tersebut, masih tidak dapat merubah kebiasaan petani yang tidak menerapkan pupuk berimbang karena adanya maindset "untung-untungan".

\section{Dampak Sosial Penurunan Kualitas Komoditas Padi di Desa Wonojati Kecamatan Jenggawah Kabupaten Jember}

Dampak merupakan pengaruh kuat yang mendatangkan suatu akibat, baik itu akibat yang negatif maupun positif. Fenomena yang terjadi di Desa Wonojati pastinya akan menimbulkan suatu dampak terhadap lingkungan di sekitarnya. Padi merupakan komoditas utama yang dibudidayakan masyarakat petani di Desa Wonojati yang merupakan sumber pendapatan utama masyarakat Desa Wonojati. Penurunan kualitas padi yang disebabkan oleh berbagai faktor seperti serangan hama dan penyakit, kondisi tanah, serta ketersediaan air akan menimbulkan dampak negatif terhadap masyarakat di Desa Wonojati, khususnya masyarakat petani. Serangan hama khususnya hama wereng akan merusak dan menurunkan kualitas dari tanaman padi. Penyakit yang biasa menyerang tanaman padi yaitu penyakit blas yang disebabkan oleh cendawan Pyricularia oryzae, awalnya akan muncul bercak pada tanaman yang kemudian akan merambat pada tangkai hingga busuk dan patah. Kondisi tanah merupakan salah satu faktor penting untuk meningkatkan produktivitas tanaman padi karena merupakan sumber tersedianya unsur hara yang dibutuhkan tanaman padi. Pemupukan harus dilakukan secara berimbang agar kondisi tanah dapat terus dalam kondisi yang baik kedepannya. Ketersediaan air merupakan kebutuhan utama tanaman padi, karena padi merupakan tanaman yang dapat tumbuh dengan baik di lahan basah atau lahan dengan ketersediaan air yang banyak. Salah satu jenis hama yang banyak menyerang padi di Desa Wonojati adalah hama wereng.

Serangan hama wereng terhadap lahan pertanian juga berdampak kepada kondisi ekonomi dan sosial di Desa Wonojati. Serangan hama wereng akan menyebabkan produktivitas lahan menurun. Menurunnya produktivitas lahan akan diatasi oleh petani dengan melakukan berbagai jenis perawatan seperti penggunaan pestisida. Banyaknya perawatan yang dilakukan tentunya akan menambah pula biaya yang dikeluarkan oleh petani, hal itu akan menyebabkan tingkat sosial masyarakat petani di Desa Wonojati semakin menurun. Masyarakat petani akan semakin kesulitan dalam memenuhi kebutuhan hidupnya karena semakin banyaknya biaya yang dikeluarkan dalam melakukan perawatan terhadap tanaman padi yang terserang hama wereng. Pemenuhan kebutuhan yang semakin sulit akan menyebabkan petani mencari uang untuk memenuhi kebutuhannya dengan meminjam uang kepada petani lainnya. Kegiatan meminjam uang ini di satu sisi berdampak positif yaitu memperat tali silaturahmi dan sikap saling membantu serta saling peduli di 
antara petani. Dampak positif yang terjadi akan berlanjut apabila petani mampu membayar hutangnya, sedangkan apabila petani tidak mampu membayar hutangnya, maka hubungan antara petani satu dengan petani yang lainnya menjadi tidak harmonis. Ketidakharmonisan yang terjadi antara dua orang petani berpengaruh terhadap hubungan dengan petani yang lainnya karena dapat terjadi tindakan saling membicarakan keburukan orang lain.

Petani di Desa Wonojati dalam melakukan penanaman padi tidak semua hasil panen ditujukan untuk memperoleh profit, melainkan disisihkan sebagian kecil untuk memenuhi kebutuhan pangan keluarganya. Dampak lainnya yang ditimbulkan akibat penurunan kualitas padi yaitu kebutuhan akan pangan masyarakat Desa Wonojati akan mengalami kekurangan sehingga mengharuskan mereka membeli untuk memenuhi kebutuhan akan pangannya. Menurunnya kualitas padi tersebut akan menurunkan kondisi ekonomi masyarakat di Desa Wonojati, karena dengan menurunnya pendapatan petani mereka tetap diharuskan untuk membeli beras untuk memenuhi kebutuhan akan pangannya yang artinya kondisi keuangan akan semakin menurun. Kondisi keuangan yang semakin menurun menyebabkan masyarakat Desa Wonojati kesulitan mendapatkan bahan makanan pokok yang digunakan untuk kehidupan seharihari.

Hasil panen padi di Desa
Wonoati sebagian dijual atau
disalurkan ke pabrik beras atau
agroindustri beras untuk diolah
menjadi beras yang siap untuk
dipasarkan. Menurunnya kualitas
akan berpengaruh terhadap
penyaluran padi dari petani ke pabrik
beras, yang mana akan mengalami

pengurangan jumlah, misalnya yang awalnya petani mengirim padi sebanyak 1 ton maka dengan menurunnya kualitas padi tersebut padi yang dikirim akan berkurang setengahnya menjadi 0,5 ton. Akibatnya pihak pabrik beras perlu mencari inputnya lagi ke petani-petani lain di daerah yang berbeda yang tentunya akan mengeluarkan biaya lebih jika lokasinya lebih jauh, karena biaya transportasi akan meningkat sesuai jarak yang ditempuh.

\section{Upaya Mengatasi Adanya Penurunan Kualitas Padi di Desa Wonojati Kecamatan Jenggawah Kabupaten Jember}

Upaya yang dilakukan pada dasarnya harus bertujuan untuk meningkatkan keuntungan dan kesejahteraan petani. Petani di Desa Wonojati juga melakukan beberapa upaya untuk mengatasi permasalahan terkait penurunan kualitas padi akibat serangan hama. Penurunan kualitas tersebut menyebabkan petani padi di Desa Wonojati mengalami gagal panen. Beberapa upaya yang dilakukan untuk dapat mengatasi masalah penurunan kualitas padi di Desa Wonojati adalah kegiatan penyuluhan dan penggunaan pestisida.

Kegiatan penyuluhan dilakukan sebagai upaya untuk memperkenalkan benih - benih berkualitas yang tahan terhadap serangan hama. Upaya yang dilakukan oleh penyuluh sendiri biasanya dilakukan dengan mengundang para petani dan mengadakan pertemuan dengan kelompok tani. Kegiatan lain yang dapat dilakukan yaitu dengan cara datang secara langsung menuju lahan dan mempraktikan bagaimana cara pemupukan yang benar serta bagaimana cara memilih benih yang memiliki kualitas unggul. Benih padi 
berkualitas adalah benih yang varietasnya diketahui dan berlabel, berseragam dan bernas serta bebas dari infeksi jamur dan penyakit. Upaya lain yang dilakukan oleh petani di Desa Wonojati adalah penggunaan pestisida kimia.

Penggunaan pestisida kimia diterapkan oleh petani karena pengendalian hama lebih cepat dibandingkan dengan pestisida organik. Pengendalian hama menggunakan pestisida kimia akan membuat hama mati pada saat itu juga, sedangkan pengendalian hama dengan pupuk organik tidak langsung mematikan hama, melainkan terlebih dahulu melemahkan serangan dari hama. Penggunaan pestisida kimia dilakukan secara tidak berlebihan. Kegiatan ini dilakukan dengan pendampingan dari penyuluh agar petani mengerti berapa dosis yang baik digunakan. Penggunaan pestisida berlebihan dapat menimbulkan serangan hama yang lebih besar bahkan mampu membuat hama padi semakin tahan terhadap pestisida yang diberikan. Penggunaan pestisida secara tepat juga menjadi salah satu program penyuluh di Desa Rowo Indah untuk mengatasi hama padi, tetapi pelaksanaannya belum dilakukan secara maksimal oleh petani.

Penyuluhan penggunaan benih yang berkualitas dan penggunaan pestisida secara tepat merupakan upaya yang hingga saat ini masih harus ditekankan pelaksanaannya kepada petani. Petani yang sudah menerapkan penggunaan benih yang berkualitas dan penggunaan pestisida secara tepat merasakan bahwa serangan hama yang terjadi memang berkurang daripada sebelumnya. Beberapa petani sudah menerapkan upaya - upaya tersebut memberitahu kepada petani yang lainnya untuk menerapkan kedua hal tersebut. Kendalanya adalah beberapa petani terkadang tidak peduli dengan saran saran yang diberikan sehingga upaya tersebut tidak dilakukan dan serangan hama masih tetap tinggi. Petani yang menggunakan benih berkualitas dan mengikuti program penyuluhan sebenarnya telah merasakan perubahan hasil pada usaha budidaya tanaman padinya.

Hasil yang didapat dari upaya yang telah dilakukan oleh petani untuk menggunakan benih yang berkualitas dan mengikuti program dari penyuluh yaitu kualitas hasil produksi yang semakin tinggi. Jumlah serangan hama pada tanaman padi juga semakin berkurang karena adanya penyuluhan menambah pengetahuan petani tentang waktu dan dosis yang tepat untuk melakukan penyemprotan pestisida. Waktu penyemprotan pestisida yang baik adalah ketika serangan hama sudah berada di atas ambang ekonomi atau tingkat populasi hama telah menyebabkan kerugian ekonomi. Dosis pestisida yang digunakan untuk penyemprotan hama biasanya sudah tertera di label kemasan produk pestisida. Waktu dan dosis pemberian pestisida yang tepat dapat mengurangi serangan hama terhadap lahan pertanian petani.

Berkurangnya serangan hama dan kualitas padi yang baik mampu meningkatkan keuntungan dan kesejahteraan petani di Desa Wonojati Kecamatan Jenggawah Kabupaten Jember. Kenaikan kesejahteraan petani di Desa Wonojati dapat dilihat melalui keadaan tempat tinggal petani yang lebih baik dengan adanya renovasi rumah. Kesejahteraan petani juga dapat dilihat dari fasilitas transportasi dimana petani dapat membeli transportasi untuk kebutuhan hidupnya. Peningkatan kesejahteraan petani di Desa Wonojati selanjutnya juga dilihat dari kemampuan petani untuk dapat 
membiayai anaknya menempuh pendidikan sampai ke jenjang perguruan tinggi. Peningkatan kesejahteraan petani dapat berpengaruh terhadap hubungan antara petani dengan penyuluh. Petani akan memiliki kepercayaan yang lebih tinggi kepada penyuluh sehingga hubungan antara petani dan penyuluh menjadi lebih baik.

\section{KESIMPULAN}

Perubahan Sosial yang terjadi di Desa Wonojati Kecamatan Jenggawah termasuk perubahan sosial yang diakibatkan oleh lingkungan luar yaitu penurunan kualitas padi yang disebabkan oleh serangan hama. Serangan hama disebabkan oleh beberapa faktor yaitu perubahan musim, pemakaian pupuk berlebihan, penyempitan saluran air dan pendidikan masyarakat Desa Wonojati yang tergolong rendah.

Dampak yang terjadi akibat penurunan kualitas padi di Desa Wonojati adalah gagal panen yang dialami petani. Gagal panen yang terjadi menyebabkan dampak ekonomi yaitu penurunan pendapatan petani serta dampak sosial berupa hubungan antar petani yang semakin baik maupun semakin buruk. Hubungan antar petani semakin baik karena meningkatkan rasa peduli dan hubungan semakin buruk karena terjadi gosip antar masyarakat yang tidak baik.

Upaya yang dilakukan masyarakat di Desa Wonojati untuk mengatasi masalah penurunan kualitas padi ada dua yaitu penyuluhan tentang penggunaan benih berkualitas dan pemakaian pupuk yang benar sesuai dengan dosis.

\section{DAFTAR PUSTAKA}

Abdullah, Mulat Wigawati. 2008. Sosiologi Untuk SMP dan MTS. Jakarta: Garasindo.

Alamsyah, F. 2015. Analisis Akar Penyebab Masalah dalam Meningkatkan Oveall Equipment Effectiveness (OEE) Mesin Stripping Hipack III dan Unimach di PT PFI. Jurnal OE, $7(3): 289-302$

Andriani, I., E. Hardi, dan L. Husnita. 2012. Perubahan Sosial Ekonomi Masyarakat Pasca Pengembangan Wisahata Bahari di Kepulauan Sikakap Kabupaten Mentawai. Ilmu Sosial Manangan, 1(2): 95-101.

Anggraini, F., Agus S. dan Nurul A. 2013. Sistem Tanam dan Umur Bibit pada Tanaman Padi Sawah (Oryza Sativa L.) Varietas Inpari 13. Produksi Tanaman, 1(2) : 52-60.

Buluara, A. J., H. Cangara dan J. M. Fatimah. 2015. Opini Tokoh Masyarakat terhadap Peranan Polisi sebagai Pelindung, Pengayom dan Pelayan Masyarakat di Daerah Rawan

Dewi, C., Mursalim, dan P. Mappigau. 2015. Permasalahan Sistem Agribisnis dan Strategi Memperbaiki Daya Saing Komoditi Markisa di Kabupaten Gowa. Agribisnis, 2(1): 21 - 40

Dianawati, M., E. Sujitno. 2015. Kajian Berbaga5Varietas Unggul Terhadap Serangan Wereng Batang Cokelat dan Produksi Padi di Lahan Sawah Kabupaten Garut, Jawa Barat. PSNMBI, 1(4): 868-873

Dwi, L. F. 2016. Pengukuran User Experience dengan Pendekatan 
Usability (Studi Kasus: Website Pariwisata di Asia Tenggara). Seminar Nasional Teknologi Informasi dan Multimedia, 1(3): $55-60$.

Evalia, N. A. 2015. Strategi Pengembangan Agroindustri Gula Semut Aren. Jurnal Manajemen \& Agribisnis, 12(1): 57-67

Ekasari, Putri dan Arya H.D. 2012. Dampak Sosial-Ekonomi Masuknya Pengaruh Internet dalam Kehidupan Remaja Di Pedesaan. Sosiologi Pedesaan, 6 (1): $57-71$.

Giachetti, R. E. 2010. Design of Enterprise Systems: Theory, Architecture, and Methods. Jakarta: CRC Press

Ginting., A. 2013. Faktor-faktor yang Mempengaruhi Produksi Padi dan Kontribusinya Terhadap Pendapatan Keluarga Petani. JURIDIKTI ,6(2): 1-62.

Gumilang, S. G. 2016. Metode Penelitian Kuantitatif dalam Bidang Bimbingan dan Konseling. Jurnal Penelitian, 2(2): $144-159$

Irwan. 2015. Dinamika dan Perubahan Sosial. Yogyakarta: Deepublish.

Ishak, A. F. 2013. Pengaruh Nilai Tambah Sektor Pertanian Terhadap Penyerapan Tenaga Kerja di Kalimantan Timur. Agribisnis Indonesiai, 1(1): 1-8.

Kaharudin, S. 2014. Analisis Perngaruh Kebijakan Pertanian G-20 Di LosCabos Meksiko 2012 Terhadap Kebijakan Pertanian Indonesia. Ilmu Hubungan Internasional, 2(2): 473: 482.
Kurniawan, W. A. 2014. Analisis Dimensi Kualitas Pelayanan Karyawan dengan Menggunakan Fishbone Analysis. 1-16

Luntungan, I., Aida V. S., Hubeis, Euis S., dan Agus M. 2014. Strategi Pengolahan Generasi Y di Industri Perbankan. Manajemen Teknologi, 13(2): 219-240.

Makeham, J.P., dan Malcolm R.L. 2007. Manajemen Usahatani Daerah Tropis. Jakarta: LP3ES.

Martono, N. 2012. Sosiologi Perubahan Sosial. Jakarta: Rajawali Pers.

Masniawati, A., Tutik Kuswinanti, Risco B. Gobel, dan Risnawati R. 2013. Identifikasi Cendawan Terbawa pada Benih Padi Lokal Aromatik Pulu Mandoti, Pulu Pinjan, dan Pare Lambau asal Kabupaten Enrekang, Sulawesi Selatan. Manasir, 1 (1): 51-59.

Mulyadi, M. 2015. Perubahan Sosial Masyarakat Agraris ke Masyarakat Industri dalam Pembangunan Masyarakat di Kecamatan Tamalate Kota Makassar. Bina Praja, 7(4): 311 322.

Mulyaningsih, I. E. 2014. Pengaruh Interaksi Sosial Keluarga, Motivasi Belajar, dan Kemandirian Belajar terhadap Prestasi Belajar. Jurnal Pendidikan dan Kebudayaan, 20(4): 441-451.

Mustikarini, F., Retnaningsih dan M. Simanjuntak. 2014. Kepuasan dan Loyalitas Petani terhadap Pestisida. Jurnal Ilmu Keluarga, 7(2) : $93-102$

Nugraha, d. R., dan A. A. Wijaya. 2015. Respon Pertumbuhan dan Hasil 
Tanaman Padi (Oryza sativa L.) Kultivar Inpari 30 pada Sistem Tanam Berbeda dan Pemberian Macam Dosis Pupuk Anorganik. Nurdiani. Junal Ilmu Pertanian dan Peternakan, 3(2): 125 - 131

Nurdiana. 2014. Teknik Sampling Snowball dalam Penelitian Lapangan. Jurnal Teknik Sampling Snowball, 5(2): 11101118.

Purwasasmita, M. dan A. Sutaryat. 2010. Padi Sri Organik Indonesia. Jakarta: Rajawali Pers

Rismahardi, G. G. 2012. Aplikasi Fishbone Analysis dalam Meningkatan Kualitas Pare Putih di Aspakusa Makmur Kabupaten Boyolali. Jurnal Agrista 1-16

Rochmah, N. L., dan Widi. A. W. 2015. Analisis Soal Tipe Higher Order Thinking Skill (HOTS) dalam Soal UN Kimia SMA Rayon B Tahun 2012/2013. Kaunia, 11(1): $27-39$.

Salmiati. 2015. Perilaku Agresif dan Penanganannya (Studi Kasus pada Siswa SMPN 8 Makassar). Psikologi Pendidikan dan Konseling, 1(1): $66-76$

Soeradi. 2013. Perubahan Sosial dan Ketahanan Keluarga: Meretas Kebijakan Berbasis Kekuatan Lokal. Informasi, 18 (2): 83 - 94.
Soetriono, A. Suwandari dan Rijanto. 2006. Pengantar Ilmu Pertanian. Jember: Universitas Jember.

Sujitno, E., M. Dianawati, dan T. Fahmi. 2014. Serangan Wereng Batang Cokelat pada Padi Varietas Unggul Baru Lahan Sawah Irigasi. Jurnal Agros, 16(2): $240-247$

Sukma, N., Adi, dan Ekowati. 2016. Analisis Harga Pokok Produksi Sapi Andinirejo dengan Sistem Pembibitan pada Anggota KTT Tri Andinirejo Kelurahan Bener Kecamatan Tegalrejo Yogyakarta. Agromedia, 34(2): $21-26$

Sutrisno, L. 2002. Pembangunan Pertanian Sebuah Tinjauan Sosiologis. Yogyakarta: Kanisius.

Tonny, F. N. 2014. Pengembangan Masyarakat. Jakarta: Yayasan Pustaka Obor Indonesia

Umayana, H. T. dan W. H. Cahyati. 2015. Dukungan Keluarga dan Tokoh Masyarakat terhadap Keaktifan Penduduk ke Posbindu Penyakit Tidak Menular. Kemas, 11(1): 96 - 101

Waluya, B. 2007. Sosiologi. Bandung: PT Setia Purna

Wanda., F.F.A. 2015. Analisis Pendapatan Usaha Tani Jeruk Siam.Ilmu Administrasi Bisnis. 3(3): 600-611.di Desa wonojati. 